\title{
A sarcopenia prevalenciája, valamint az egészség- és életmódbeli tényezőkkel való kapcsolata a tartós ellátást nyújtó intézményekben élő idősek körében
}

\author{
Kovács Éva dr. ${ }^{1}$ - Jónásné Sztruhár Izabella ${ }^{2,4}$. Asiama Evelyn ${ }^{1}$ \\ Karóczi Csilla Kata ${ }^{1}$. Gondos Tibor $\mathrm{dr}^{3}$ \\ Semmelweis Egyetem, Egészségtudományi Kar, \\ ${ }^{1}$ Alapozó Egészségtudományi Intézet, Morfológiai és Fiziológiai Tanszék, \\ ${ }^{2}$ Alkalmazott Egészségtudományi Intézet, Fizioterápia Tanszék, \\ ${ }^{3}$ Egészségfejlesztési és Klinikai Módszertani Intézet, Egészségtudományi Klinikai Tanszék, Budapest \\ ${ }^{4}$ Fővárosi Önkormányzat Pesti Úti Idősek Otthona és Regionális Módszertani Osztály, Budapest
}

\begin{abstract}
Bevezetés: A korábbi, sarcopeniát vizsgáló tanulmányokat otthon élő vagy kórházi ellátásban részesülő idősek körében végezték. Hiányoznak azok a kutatások, amelyek a tartós ellátást nyújtó intézményekben élő idősekre irányulnak. Célkitüzés: A sarcopenia gyakoriságának, valamint egészségbeli és életmódbeli tényezőkkel való összefüggésének vizsgálata a tartós ellátást nyújtó ápolóotthonban élő idősek körében. Módszer: A vizsgálatban 205 személy vett részt. A sarcopeniát az izomtömeg, az izomerő és a funkcionális kivitelezés alapján diagnosztizálták. Független változók voltak: funkcionális mobilitás, fehérjebevitel, dohányzás, jelenleg és középkorúként végzett fizikai aktivitás, krónikus betegségek és korábbi elesés. Az összefüggéseket egy- és többváltozós modellben vizsgálták. Eredmények: Összesen 73 résztvevőnek volt sarcopeniája. A sarcopenia a dohányzással, a multimorbiditással, a funkcionális mobilitással és a középkorúként végzett fizikai aktivitással mutatott összefüggést. Következtetés: A kutatás arra mutatott rá, hogy az egészségbeli és életmódbeli tényezőknek fontos szerepe van a sarcopenia gyakoriságában. Orv. Hetil., 2016, 157(46), 1847-1853.
\end{abstract}

Kulcsszavak: sarcopenia, izomtömeg, idős emberek, tartós ellátást nyújtó intézmények

\section{Prevalence and associated factors of sarcopenia among older adults living in institutions providing long-term care}

Introduction: Earlier studies dealing with sarcopenia were conducted among community-living or hospitalized older adults; however, to date, study focusing on older adults living in institutions providing long-term care is lacking. Aim: The aim of this study was to describe the prevalence of sarcopenia and its associations with lifestyle and health factors among older people living in institutions providing long-term care. Method: Two hundred five individuals participated in the study. Sarcopenia was diagnosed based on muscle mass, muscle strength and functional performance. The independent variables were functional mobility, protein intake, smoking, current physical activity, and physical activity when middle-aged, multimorbidity, and falls in the previous year. Univariate models and a multivariate model were used to assess associations. Results: In total 73 participants had sarcopenia. Sarcopenia was associated with smoking, multimorbidity, physically active lifestyle when middle aged, and functional mobility. Conclusion: This study showed that lifestyle factors and health condition have important roles in the prevalence of sarcopenia.

Keywords: sarcopenia, prevalence, muscle mass, older people, institutions providing long-term care

Kovács, É., J. Sztruhár, I., Asiama, E., Karóczi, Cs. K., Gondos, T. [Prevalence and associated factors of sarcopenia among older adults living in institutions providing long-term care]. Orv. Hetil., 2016, 157(46), 1847-1853.

(Beérkezett: 2016. augusztus 15.; elfogadva: 2016. szeptember 25.) 


\section{Rövidítések}

$\mathrm{BMI}=($ body mass index $)$ testtömegindex; $\mathrm{EH}=$ esélyhányados; $\mathrm{MT}=$ megbízhatósági tartomány; $\mathrm{SMI}=$ (skeletal mass index) vázizomindex; $\mathrm{SPPB}=($ Short Physical Performance Battery) „rövidített fizikális kivitelezés teszt”

Régóta ismert, hogy a vázizomzat tömege és ereje az idősödéssel csökken [1]. A szervezet a harmincas életévekre éri el a maximális izomtömeget, ami néhány évig megmarad, majd 40 éves életkortól progresszíven csökken: kezdetben dekádonként 8\%-kal, majd 70 éves kortól 15\%-kal. Így a nyolcvanas életévekre az izomtömeg a fiatalkori átlagnak közel a felére fogyatkozik [2]. Rosenberg ezt az izomvesztést nevezte sarcopeniának [3]. Ma a sarcopeniát geriátria szindrómának tekintik, amelynek egyik eleme a megfogyatkozott izomtömeg, amit vagy az izomerő, vagy a funkcionális képességek, vagy mindkettő hanyatlása kísér [4].

A sarcopeniának számos funkcionális és metabolikus következménye van. A kisebb izomtömeg és a csökkenő teherbírás miatti inaktivitás következtében csökken az energiaszükséglet - ami változatlan táplálkozás mellett elhízáshoz, majd inzulinrezisztenciához, cukorbetegséghez, hyperlipidaemiához, hypertoniához vezethet [5]. Az izomtömeg- és izomerő-csökkenés lényeges faktora az időskori eleséseknek, az önellátási képesség elvesztésének $[6,7]$. A sarcopenia prevalenciája a 60-70 évesek között 5-13\% [8,9], míg a 80 évesnél idősebbeknél vizsgálati módszertôll függő́en 19-53\%-os [10, 11$]$.

Az idősek számarányának növekedésével és a várható élettartam meghosszabbodásával, hatékony prevenciós és terápiás intézkedések nélkül a sarcopenia és következményei egyre nagyobb lelki, fizikai problémákat és anyagi terhet fognak jelenteni az egyénnek, a közvetlen környezetének és a társadalomnak $[7,12]$. A hatékony intézkedések megtervezéséhez a sarcopenia patomechanizmusa mellett a sarcopeniával kapcsolatban álló, azt befolyásoló életmódbeli tényezők ismerete is szükséges. A korábbi kutatások otthon élő idősek körében vizsgálták a sarcopenia prevalenciáját, valamint azt, hogy az egészség- és életmódbeli tényező́k hogyan függnek öszsze a sarcopenia gyakoriságával [8, 13-19]. Eddig azonban azt nem vizsgálták, hogy a tartós ellátást nyújtó idősotthonban élőknél van-e összefüggés a fenti tényezôk és a sarcopenia előfordulása között.

Keresztmetszeti kutatásunkban ezért a tartós ellátást nyújtó intézményben vizsgáltuk a sarcopenia prevalenciáját. Kutatásunk további célja az volt, hogy meghatározzuk, van-e kapcsolat a sarcopenia gyakorisága és az idős életszakaszt jellemző életmódbeli tényezők (a dohányzás, a táplálék fehérjetartalma és a fizikai aktivitás), az egészségi állapot (az egy éven belüli elesés, multimorbiditás és a funkcionális stabilitás), valamint a korábbi életszakasz fizikai aktivitása között.

\section{Módszer}

\section{Résztvevők}

A 60 évesnél idősebbek közül azokat vontuk be a vizsgálatba, akik járási segédeszközzel vagy személyi segítséggel legalább 6 métert képesek voltak megtenni, és önként vállalták a méréseken való részvételt. Az intézmény 544 lakója közül 210 személy felelt meg a beválasztás kritériumainak. Közülük 205 személy vett részt az adatfelvételen és a méréseken, amelyeket két fizioterapeuta és egy dietetikus végzett. Kutatásunkat az 1975-ös Helsinki Nyilatkozat 2008. évi revíziójának alapelveit betartva végeztük.

\section{Mérések}

A sarcopenia meglétét az Időskori Sarcopenia Európai Munkacsoport kritériumai alapján a vázizomtömeg, az izomerő és a funkcionális teljesítmény ismeretében határoztuk meg [4]. A vázizomtömeget a bioelektromos impedanciaanalízis elvén múködő InBody 370 (8 felületi elektródával, $50 \mathrm{kHz}$ frekvenciával múködő) készülékkel mértük [20]. A múszer az egyes testszövetek mennyiségét a testen áthaladó áram intenzitásából és a mért ellenállásból kiszámítja és digitálisan kijelzi. A résztvevőket megkértük, hogy a mérés előtt 1 órával ne fogyasszanak ételt és italt, valamint tartózkodjanak a mozgásgyakorlatoktól. A vázizomtömegből vázizomindexet (skeletal mass index - SMI) számítottunk, ami a vázizomtömeg és a testmagasság négyzetének hányadosa. A vázizomidexet életkornak és nemnek megfelelő normálértékhez viszonyítottuk [4].

A funkcionális teljesítményt a „rövidített fizikális kivitelezés teszt"-tel (Short Physical Performance Battery SPPB) mértük, amely három - a napi aktivitásoknak megfelelő - funkciót (a statikus állást, a járássebességet és az ülésből felállást) vizsgál és pontoz, tökéletes teljesítmény esetén összesen 12 ponttal $[4,21]$.

$\mathrm{Az}$ izomerőt a standard tesztpozícióban, dinamométerrel mért kézszorító erő alapján ítéltük meg, amely szorosan korrelál a test általános izomerejével [22]. A domináns kéz teljesítményét a nemnek, életkornak és BMI-nek megfelelő normálértékekhez viszonyítva ítéltük meg [4]. A funkcionális mobilitást a Timed Up and Go teszttel vizsgáltuk. A teszt feladata az volt, hogy a résztvevő egy „Rajt!” jelzésre álljon fel egy standard magasságú $(46 \mathrm{~cm})$ karosszékről, menjen el 3 méterre, majd egy tárgy megkerülése után sétáljon vissza és üljön vissza a székre [23].

A fehérjebevitelt a 24 órás Food Recall módszerrel mértük fel: a módszer lényege, hogy az idős személyt a tárgynapot megelőző 24 órában fogyasztott ételekről, italokról kérdeztük $[24,25]$. Nem csupán a fóétkezések fogásait jegyeztük fel, hanem minden, a nap során elfogyasztott élelmiszert és folyadékot. Az elfogyasztott éte- 
lek adatait a NutriComp Étrend Sport 3.0 szoftver segítségével dolgoztuk fel, amely kiadta az ételek fehérjetartalmát. A kapott értéket a testtömegnek megfelelő fehérjeigényhez - ami krónikus betegségek által veszélyeztetett időseknél legalább 1,2 g/ttkg/nap - viszonyítottuk [26].

Az idős emberekkel folytatott személyes interjú során kérdeztünk rá a dohányzásra és a 40-60 éves koruk között végzett fizikai aktivitásra. A dohányzási szokásokra vonatkozó kérdés alapjául az Országos Lakossági Egészségfelmérés dohányzásra vonatkozó vizsgálati szempontja szolgált: Dohányzik-e napi rendszerességgel? Nemleges válasz esetén: Dohányzott-e valaha? Mikor szokott le? [27]. A visszaemlékezésen alapuló fizikai aktivitás kérdéstechnikájában a korábbi kutatások módszertanát követtük [28, 29]: „Visszaemlékezve a 40-es és 50-es életéveire, végzett-e olyan, legalább egy órát kitevő időtartamú sportot vagy szabadidős mozgást, ami megizzasztotta, szaporább légvételre késztette (futás, kocogás, úszás, biciklizés, labdajátékok, erőteljes gyaloglás)?” Igen válasz esetén: „Milyen gyakran?” A visszaidézni kívánt életszakaszt valamilyen életeseményhez kötve próbáltuk pontosítani (például, amikor a gyermekei érettségiztek, amikor a gyermeke házasodott, amikor a munkahelyén valamilyen pozíciót töltött be).

A demográfiai adatokat, a társbetegségeket, a rendszeresen szedett gyógyszereket és a kutatást megelőző 12 hónapos időszakban történt elesések számát az egészségügyi dokumentációból gyújtöttük.

\section{Statisztikai elemzés}

A mintát leíró statisztikai adatokat folyamatos adatok esetén átlagban ( \pm szórás), a kategorikus adatok esetén pedig abszolút és relatív gyakoriságban adtuk meg. Az adatok normalitásáról a Kolmogorov-Szmirnov-teszt eredménye alapján döntöttünk.

A következő változókra vonatkozó folyamatos vagy többértékű kategorikus adatokat kétértékűvé alakítottuk:

- sarcopenia $(0$ = nincs; 1 = van, ha praesarcopenia vagy sarcopenia határozható meg az európai sarcopeniamunkacsoport által publikált kritériumok alapján [4];

- dohányzás ( 0 = soha vagy leszoktam már több mint 12 hónapja; 1 = jelenleg is van vagy 12 hónapon belül szoktam le);

- jelenlegi fizikai aktivitás ( 1 = hetente két alkalommal legalább 50-60 perces tempós séta vagy irányított geriátriai torna; $0=$ sohasem vagy az előzőnél ritkábban);

- korábbi fizikai aktivitás ( 1 = rendszeres, legalább heti kétszeri sport- vagy szabadidős tevékenység, például atlétika, labdajátékok, kirándulás több éven keresztül 40-60 éves korban; 0 = soha vagy az előzőnél ritkábban, alkalomszerüen);

- multimorbiditás $(0=$ nem beteg vagy a következő betegségekből legfeljebb csak egy áll fenn: diabetes mel- litus, kardiorespiratorikus, mozgásszervi, mozgásképességet is befolyásoló neurológiai betegség [Parkinson-kór, stroke, polineuropathia]; 1 = egy betegségnél több van) [30];

- alacsony fehérjebevitel: 1 = fennáll, ha az ajánlott optimális napi adag (amely idős emberek esetén 1,2 g/ ttkg) 90\%-át nem éri el [26].

A sarcopeniás és a nem sarcopeniás csoportot az adatok minőségétől függően független mintás t-próbával, valamint $\chi^{2}$-próbával hasonlítottuk össze.

Ezt követően binomiális logisztikus regresszióval (Enter módszer) elemeztük a sarcopenia mint függő változó, valamint a sarcopeniával feltételezhetően kapcsolatban álló életmódbeli tényezők (dohányzás időskorban, valamint 40-60 éves életkorban végzett fizikai aktivitás, a táplálék fehérjetartalma) és egészségbeli tényezők (multimorbiditás, funkcionális mobilitás, korábbi évben történt elesés) mint független változók kapcsolatát. Első lépésben egyváltozós elemzésben a sarcopenia és a független változók közti kapcsolatot vizsgáltuk, és esélyhányadost (EH) számítottunk, amely megmutatja, hogy van-e és milyen erős a kapcsolat az adott tényező és a sarcopenia gyakorisága között. A többváltozós elemzésbe azokat a változókat vontuk be, amelyeknek a sarcopenia gyakoriságával való összefüggése egyváltozós elemzésben 0,25 alatti szignifikanciát mutatott. Az összefüggés szignifikanciájának megállapításához 95\%-os megbízhatósági tartományt (MT) számítottunk, amelyet akkor értékeltünk szignifikánsnak, ha nem tartalmazta az 1-et. A többváltozós modell magyarázó erejét a Nagelkerle $\mathrm{R}^{2}$ megadásával jellemeztük, amely megmutatja, hogy a független változókat tartalmazó modell a függó változó varianciájának hány százalékát magyarázza meg. A statisztikai számításokhoz SPSS statisztikai programot használtunk.

\section{Eredmények}

A vizsgálatban részt vevők átlagéletkora 73 év volt, a legfiatalabb résztvevő 60 éves, a legidősebb 99 éves volt. A nők aránya $73 \%$ volt. Mozgásszervi betegségben 31 személy szenvedett, kardiorespiratorikus betegségben 72 személy, cukorbetegség 49 személynél állt fenn, neurológiai betegség 40 személynél (1. táblázat). A sarcopenia összesen 73 személynél (35\%) volt diagnosztizálható.

A 2. táblázatban a bináris logisztikus regressziós analízisek eredményeit mutatjuk be, amelyek segítségével a sarcopenia és a független változók közötti kapcsolatot vizsgáltuk.

Az eredmények szerint a korábbi fizikai aktivitás és a sarcopenia között szignifikáns kapcsolat áll fent: közel 68\%-kal kisebb az időskori sarcopenia gyakorisága, ha a személy korábbi életszakaszát fizikailag aktív életmód jellemezte. A többváltozós elemzés azt igazolta, hogy ez a kapcsolat akkor is érvényesül, ha a többi tényező hatását is figyelembe vesszük. 
1. táblázat |A minta jellemzői

\begin{tabular}{|c|c|c|c|}
\hline & $\begin{array}{l}\text { Nincs } \\
\text { sarcopenia } \\
(\mathrm{n}=132)\end{array}$ & $\begin{array}{l}\text { Van } \\
\text { sarcopenia } \\
(\mathrm{n}=73)\end{array}$ & p-érték \\
\hline Életkor (év), átlag \pm szórás & $73,2 \pm 12,5$ & $72,3 \pm 11,4$ & 0,563 \\
\hline Nők, n (\%) & $116(87,9)$ & $25(34,2)$ & $<0,001$ \\
\hline BMI $\left(\mathrm{kg} / \mathrm{m}^{2}\right)$, átlag \pm szórás & $27,3 \pm 5,4$ & $23,5 \pm 4,6$ & $<0,001$ \\
\hline Jelenleg dohányzik, n (\%) & $23(17,4)$ & $33(45,2)$ & $<0,001$ \\
\hline $\begin{array}{l}\text { Középkorúként fizikailag } \\
\text { aktív, n (\%) }\end{array}$ & $53(40,2)$ & $16(21,9)$ & 0,001 \\
\hline Jelenleg fizikailag aktív, n (\%) & $74(56,1)$ & $41(56,2)$ & 0,557 \\
\hline \multicolumn{4}{|l|}{ Egészségi állapot } \\
\hline Csontritkulás, n (\%) & $11(8,3)$ & $5(6,8)$ & 0,468 \\
\hline $\begin{array}{l}\text { Kardiorespiratorikus } \\
\text { betegség, n (\%) }\end{array}$ & $36(27,2)$ & $36(49,3)$ & 0,002 \\
\hline Diabetes mellitus, n (\%) & $36(27,2)$ & $13(17,8)$ & 0,125 \\
\hline Demencia, n (\%) & $45(34,1)$ & $30(41,1)$ & 0,283 \\
\hline $\begin{array}{l}\text { Mozgásszervi betegség, } \\
\mathrm{n}(\%)\end{array}$ & $20(15,2)$ & $11(15,1)$ & 0,808 \\
\hline Neurológiai betegség, n (\%) & $23(17,4)$ & $17(23,3)$ & 0,485 \\
\hline $\begin{array}{l}\text { Járási segédeszköz } \\
\text { használata, n }(\%)\end{array}$ & $40(30,3)$ & $22(30,1)$ & 0,731 \\
\hline Előző évben elesett, n (\%) & $37(28)$ & $19(26)$ & 0,734 \\
\hline
\end{tabular}

$\mathrm{BMI}=($ body mass index $)$ testtömegindex.

2. táblázat $\mid$ Az életmód- és egészségbeli tényezők, valamint a sarcopenia gyakorisága közti összefüggés egyváltozós és többváltozós elemzésben

\begin{tabular}{lll}
\hline & $\begin{array}{l}\text { Esélyhányados } \\
\text { és 95\%-os } \\
\text { megbízhatósági } \\
\text { tartomány } \\
\text { egyváltozós } \\
\text { elemzésben }\end{array}$ & $\begin{array}{l}\text { Esélyhányados } \\
\text { és 95\%-os } \\
\text { megbízhatósági } \\
\text { tartomány } \\
\text { többváltozós } \\
\text { elemzésben }\end{array}$ \\
\hline Dohányzás & $4,69(2,39-9,17)$ & $5,82(2,42-13,00)$ \\
\hline Multimorbiditás & $6,99(3,62-13,52)$ & $4,28(1,91-9,57)$ \\
\hline $\begin{array}{l}\text { Középkorúként űzött } \\
\text { fizikai aktivitás }\end{array}$ & $0,32(0,16-0,64)$ & $0,32(0,13-0,75)$ \\
\hline Funkcionális mobilitás & $1,05(1,02-1,08)$ & $1,05(1,01-1,09)$ \\
\hline $\begin{array}{l}\text { Előzó évben történt } \\
\text { elesés }\end{array}$ & $1,12(0,69-2,14)$ & \\
\hline $\begin{array}{l}\text { Jelenleg úzött fizikai } \\
\text { aktivitás }\end{array}$ & $0,83(0,44-1,56)$ & \\
\hline Alacsony fehérjebevitel & $1,15(0,59-2,22)$ & \\
\hline
\end{tabular}

Ugyancsak szignifikáns kapcsolat igazolódott a funkcionális mobilitás és a sarcopenia között: ha akár csak 1 másodperccel rosszabb funkcionális mobilitással rendelkezik az idős személy, akkor több mint 5\%-kal magasabb a sarcopenia gyakorisága. Ez a kapcsolat megmarad a többi tényező hatása mellett is.
A dohányzás és a sarcopenia között egyváltozós elemzésben szignifikáns kapcsolat igazolódott, amely kapcsolat a többi tényező bevonása esetén is megmaradt, azaz a jelenlegi dohányzás mellett több mint ötszörös a sarcopenia kialakulásának esélye.

A jelenlegi fizikai aktivitás, az egy éven belüli elesés hatása, valamint az, hogy az elfogyasztott táplálék fehérjetartalma nem éri el az idős személyekre vonatkozó szükségletet, nem bizonyult szignifikánsnak.

A szignifikáns kapcsolatot mutató tényezőkből álló modellünk a függő változó varianciájának $40 \%$-át magyarázza.

\section{Megbeszélés}

Kutatásunkban azt vizsgáltuk, hogy milyen összefüggés mutatkozik a tartós ellátást nyújtó intézményben élő időseknél az idős életszakaszt jellemző életmódbeli tényezők (dohányzás, időskori fizikai aktivitás, fehérjebevitel) és egészségbeli tényezők (multimorbiditás, az egy éven belüli elesés, funkcionális stabilitás), valamint a korábbi életszakasz fizikai aktivitása és a sarcopenia között. Az eredményeink alapján felvetődött a dohányzásnak és a rossz funkcionális mobilitásnak veszélyeztető hatása, valamint a korábbi fizikai aktivitás preventív hatása.

Számos epidemiológiai kutatás vizsgálta a sarcopenia kialakulását feltételezhetően befolyásoló tényezők hatását, azonban a kutatások többségét otthon élő idősek körében végezték.

Hwang és mtsai 2221 fös, koreai, otthon élő idősekből álló mintán azt észlelték, hogy a krónikus betegségek jelenléte szignifikánsan összefügg a sarcopeniával: két krónikus betegség öt és félszeresére, három vagy annál több betegség tíz és félszeresére növeli a sarcopenia esélyét [15]. A fenti kutatásban a jelenlegi fizikai aktivitás befolyásoló hatását vizsgálva sem az ellenállással szemben végzett gyakorlatok, sem a mobilitást növelő mozgásprogramok, sem a járástréning prevenciós hatása nem igazolódott. Chien és mtsai egy 275 fós, tajvani, otthon élő idősekből álló mintát vizsgálva arra mutattak rá, hogy azoknál, akiknek nehézségeik vannak a mindennapi élet alapmozgásainak kivitelezésében, háromszoros a sarcopenia gyakorisága [14]. Castillo és mtsai $(\mathrm{n}=1700)$ eredményei szerint esélynövelő hatása van a 85 év feletti életkornak és a korábbi elesésnek. Ebben a kutatásban a jelenlegi fizikai aktivitás csak a nóknél volt preventív hatású, a férfiaknál ez a hatás nem igazolódott. A krónikus betegségek fennállása nem bizonyult befolyásoló tényezőnek [13]. Baumgartner és mtsai egy 808 fós mintán vizsgálták a dohányzás, a mobilitás, az alkoholfogyasztás, a korábbi elesés és a jelenlegi fizikai aktivitás hatását. Az első két vizsgált tényező veszélyeztető hatása igazolódott, míg a többi három tényező hatása nem bizonyult szignifikánsnak [8]. Volpato az otthon élő idősek körében nem igazolta a jelenlegi fizikai aktivitás, a multimorbiditás és a táplálkozás hatását sarcopeniában, míg az iskolázottság szerepét szignifikánsnak találta [19]. Pong- 
chaiyakul kutatása elsősorban a sarcopenia prevalenciájára irányult, a befolyásoló faktorok közül csak a városban élés és a BMI hatását vizsgálta, amelyek szignifikánsnak bizonyultak [17]. Habár a különböző kutatásokból származó eredmények összehasonlítását nehezíti az, hogy a kutatócsoportok eltérő kritériumok alapján állították fel a sarcopenia diagnózisát, saját kutatásunk eredménye számos tekintetben összhangban van a nemzetközi kutatások eredményeivel. Mi intézetben élő időseknél vizsgáltuk a sarcopenia összefüggését olyan tényezőkkel, amelyeket az otthon élő időseknél korábbi kutatások már elemeztek. A dohányzás és a krónikus betegségek veszélyeztető hatását mi is tapasztaltuk. A korábbi kutatásoktól eltérően mi nemcsak a jelenlegi, hanem a korábbi életszakasz fizikai aktivitásaira is rákérdeztünk. Kutatásunk az elsőnek nem, csak az utóbbinak a preventív hatására mutatott rá.

A prevalenciában jelentős különbségek vannak az egyes kutatások eredményei között: az Egyesült Királyságban 7,8\%-os prevalenciát becsültek [16]. Brazil, japán és koreai populációban 12-22\% között mozgott a kimutatott gyakorisági adat $[18,31,32]$. Olaszországi kutatók tanulmányában a nők 31,6\%-a, a férfiak 17,4\%-a volt érintett [19]. A cukorbetegségben szenvedő indiai populációban mérték a legnagyobb, 39,5\%-os gyakoriságot [33].

Az ellentmondásos eredmények fakadhatnak az eltérő mintanagyságból, valamint abból, hogy eltérő kritériumok alapján és eltérő módszerrel meghatározott izomtömegből állították fel a sarcopenia diagnózisát. A gazdagabb országok kutatói az izomtömeget a magas szenzitivitású és magas specificitású DEXA (dual-energy X-ray absorptiometry) -módszerrel mérték. A kutatásunkban is alkalmazott bioelektromos impedancián alapuló technika relatíve olcsó, gyors és nem jelent sugárterhelést, viszont mind a specificitása, mind a szenzitivitása csak közepes [2]. Rajtunk kívül csak az olasz kutatócsoport követte az Időskori Sarcopenia Európai Munkacsoport komplex diagnosztikus irányelvét, amely három tényező (izomtömeg, izomerő, funkcióképesség) eredményén alapul [4]. A többi kutatásban csak az izomtömeget vették figyelembe. Eddig csak két kutatást végeztek intézményi keretek közt élő idősek körében, és mindkét esetben akut kórházi ellátásban részesülő idősek alkották a vizsgálat mintáját. Gariballa és Alessa [9] 10\%-os, Martinez és mtsai [34] 21,8\%-os prevalenciáról számoltak be.

Kutatásunk eredményei felhívják a figyelmet arra, hogy az aktív életszakasz (a kutatásunkban vizsgált 40 és 60 év közötti életkor) fizikai aktivitásának nagy a jelentősége az időskori sarcopenia megelőzésében. Rámutat arra is, hogy a módosítható tényezők közül a dohányzásnak és a funkcionális stabilitásnak is nagy szerepe van.

A fehérjebevitel és a sarcopenia gyakorisága közti öszszefüggést vizsgálva a kapcsolatot sem Volpato [19], sem Walsh kutatása [35] nem igazolta. Saját kutatásunkban sem igazolódott az az összefüggés, miszerint kisebb len- ne a sarcopenia előfordulása, ha az idős személy által elfogyasztott táplálék fehérjetartalma eléri a legújabb ajánlásoknak megfelelő értéket, amely krónikus betegségben szenvedő idős személyeknél legalább 1,2g/ttkg/nap. A meglepő eredmény hátterében az állhat, hogy nemcsak a táplálék fehérjetartalma, hanem az aminosav-öszszetétel, különösen a leucintartalom határozza meg a test izomtömegét [36]. Ez az elágazó láncú esszenciális aminosav aktiválja mind az inzulinfüggő, mind pedig az inzulintól független jelátviteli utat a fehérjeszintézis folyamatában, ezzel támogatva az izom-hipertrófia folyamatát [37]. A kezdeti laboratóriumi vizsgálatok, majd a humán kutatások arra is rámutatnak, hogy a bevitt fehérjemennyiség napi eloszlása is szerepet játszik [38, 39]. Minden fótkezésre ajánlott 20-30 grammos magas minőségü fehérjét biztosítani, vagyis a reggeli, az ebéd és a vacsora proteintartalma is közel azonos legyen. Ezzel a fehérjeszintézis folyamatát maximalizálni lehet [40]. Az összefüggés hiányát az is magyarázhatja, hogy az idős személyek a gyakorlatokat nem elegendő ellenállással vagy nem elegendő ismétlésszámmal végezték. Végül az is magyarázat lehet, hogy a megfelelő mennyiségű és öszszetételü fehérje elfogyasztása és az ellenállásos tréning időbeli viszonyának fontos szerepe van. Az izomfehérjeszintézis akkor a legnagyobb mértékü, ha a fehérjében gazdag táplálék elfogyasztása az ellenállásos tréning után közvetlenül vagy 1 órán belül történik $[36,41]$. További kutatásokban az elfogyasztott fehérje napi eloszlásának, a táplálék leucintartalmának, valamint a fehérjebevitel és az ellenállásos tréning időbeli viszonyának hatását is érdemes vizsgálni. Ehhez a kutatáshoz azonban olyan nagyszámú mintára lesz szükség, amit csak multicentrikus kutatás formájában - több intézmény összefogásával - lehet lefolytatni. Ez hozzájárulna a már ígéretesnek mutatkozó terápiás beavatkozások hatásának pontosabb bizonyításához is [42].

Vizsgálatunk hiányosságának tekinthető, hogy a 24 órás Food Recall módszerrel felmért fehérjebevitel csak a tárgynapot megelőző napon fogyasztott élelmiszerekre kérdez rá, ami nem biztos, hogy a szokásos táplálkozást tükrözi. A kutatás eredményét befolyásolja az is, hogy a korábbi életszakasz fizikai aktivitásának felmérése az úgynevezett visszaemlékezési hibával terhelt, még akkor is, ha részletes kikérdezés során mértük fel. Bízunk abban, hogy az idős emberek ennyi idő távlatából csak arra a fizikai aktivitásra emlékeztek, amit rendszeresen, hosszú távon végeztek. Felmérésünk keresztmetszeti elrendezése nem teszi lehetővé az oksági viszonyok pontos feltárását. Ezért fontosnak tartjuk a jelen kutatásunkban elemzett kérdések megvizsgálását longitudinális kutatási elrendezésben. Tekintve a sarcopenia kialakulásának dinamikáját (a 40-50-es életévekre tehető kezdet, valamint a vázizomtömeg küszöbérték alá való csökkenése több évtizedes folyamat után történik), a hosszú követési idejü, ezért költséges prospektív kutatások helyett elsősorban a kevésbé költséges, bár emlékezési hibával terhelt retrospektív kutatások kivitelezhetők. 


\section{Következtetés}

Összefoglalásképpen elmondhatjuk, hogy különösen azok az idős emberek vannak kitéve a sarcopenia veszélyének, akik dohányoznak, hanyatló funkcionális mobilitásúak, és a 40 és 60 év közti életszakaszukban inaktív életmódot folytattak. Az oksági kapcsolat bizonyítására további kutatások szükségesek. Már az időskort megelőző (középkorúnak nevezett) életszakaszban nagyobb hangsúlyt kellene helyezni arra, hogy a fizikailag aktív életmód lehetőségei (megfelelő, a mozgás, a fizikai aktivitás lehetőségét biztosító környezet, megfelelő mozgásprogramok) populációs szinten legyenek biztosítva.

Reméljük, hogy kutatásunk támpontot ad a feltárásra váró kérdéseket vizsgáló további kutatásokhoz, azt segítve, hogy már a középkorú életszakaszban tudatos életvezetéssel megelőzhessük vagy késleltethessük az időskori sarcopenia kialakulását.

Anyagi támogatás: A közlemény megírása anyagi támogatásban nem részesült.

Szerzői munkamegosztás: K. É.: A hipotézisek kidolgozása, a kézirat elkészítése, a vizsgálat megtervezése, statisztikai elemzés. J. Sz. I.: A vizsgálat megtervezése és lefolytatása. A. E.: A vizsgálat megtervezése és lefolytatása, a kézirat megszövegezése. K. Cs. K.: A vizsgálat lefolytatása. G. T.: A vizsgálat megtervezése, statisztikai elemzés, a kézirat elkészítése. A cikk végleges változatát valamennyi szerző elolvasta és jóváhagyta.

Érdekeltségek: A szerzőknek nincsenek érdekeltségeik.

\section{Irodalom}

[1] Jones, T. E., Stephenson, K. W., King, J. G., et al.: Sarcopenia mechanisms and treatments. J. Geriatr. Phys. Ther., 2009, 32(2), 83-89.

[2] Malafarina, V., Uriz-Otano, F., Iniesta, R., et al.: Sarcopenia in the elderly: diagnosis, physiopathology and treatment. Maturitas, 2012, 71(2), 109-114.

[3] Latham, N.: Physiotherapy to treat sarcopenia in older adults. N. Z. J. Physother., 2004, 32(1), 16-21.

[4] Cruz-Jentoft, A. J., Baeyens, J. P., Bawer, J. M., et al.: Sarcopenia: European consensus on definition and diagnosis. Report of the European Working Group on Sarcopenia in Older People. Age Ageing, 2010, 39(4), 412-423.

[5] Clark, B. C., Manini, T. M.: Functional consequences of sarcopenia and dynapenia in the elderly. Curr. Opin. Clin. Nutr. Metab. Care, 2010, 13(3), 271-276.

[6] Lang, T., Streeper, T., Cawthon, P., et al.: Sarcopenia: etiology, clinical consequences, intervention, and assessment. Osteoporos. Int., 2010, 2l(4), 543-559.

[7] Di Monaco, M., Vallero, F., Di Monaco, R., et al.: Prevalence of sarcopenia and its association with osteoporosis in 313 older women following a hip fracture. Arch. Gerontol. Geriatr., 2011, 52(1), 71-74.

[8] Baumgartner, R. N., Koehler, K. M., Gallagher, D., et al.: Epidemiology of sarcopenia among the elderly in New Mexico. Am. J. Epidemiol., 1998, 147(8), 755-763.
[9] Gariballa, S., Alessa, A.: Sarcopenia: prevalence and prognostic significance in hospitalized patients. Clin. Nutr., 2013, 32(5), 772-776.

[10] Iannuzzi-Sucich, M., Prestwood, K. M., Kenny, A. M.: Prevalence of sarcopenia and predictors of skeletal muscle mass in healthy, older men and women. J. Gerontol. A Biol. Sci. Med. Sci., 2002, 57(12), M772-M777.

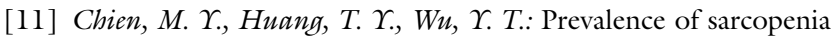
estimated using a bioelectrical impedance analysis prediction equation in community-dwelling elderly people in Taiwan. J. Am. Geriatr. Soc., 2008, 56(9), 1710-1715.

[12] Janssen, I., Baumgartner, R. N., Ross, R., et al.: Skeletal muscle cutpoints associated with elevated physical disability risk in older men and women. Am. J. Epidemiol., 2004, 159(4), 413-421.

[13] Castillo, E. M., Goodman-Gruen, D., Kritz-Silverstein, D., et al.: Sarcopenia in elderly men and women: the Rancho Bernardo study. Am. J. Prev. Med., 2003, 25(3), 226-231.

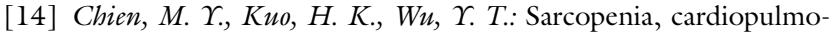
nary fitness, and physical disability in community-dwelling elderly people. Phys. Ther., 2010, 90(9), 1277-1287.

[15] Hwang, B., Lim, J. Ү., Lee, J., et al.: Prevalence rate and associated factors of sarcopenic obesity in Korean elderly population. J. Korean Med. Sci., 2012, 27(7), 748-755.

[16] Patel, H. P., Syddall, H. E., Jameson, K., et al.: Prevalence of sarcopenia in community-dwelling older people in the UK using the European Working Group on Sarcopenia in Older People (EWGSOP) definition: findings from the Hertfordshire Cohort Study (HCS). Age Ageing, 2013, 42(3), 378-384.

[17] Pongchaiyakul, C., Limpawattana, P., Kotruchin, P., et al.: Prevalence of sarcopenia and associated factors among Thai population. J. Bone Miner. Metab., 2013, 31(3), 346-350.

[18] Alexandre, T. S., Duarte, Y. A., Santos, J. L., et al.: Prevalence and associated factors of sarcopenia among elderly in Brazil: findings from the SABE study. J. Nutr. Health Aging, 2014, 18(3), 284-290.

[19] Volpato, S., Bianchi, L., Cherubini, A., et al.: Prevalence and clinical correlates of sarcopenia in community-dwelling older people: application of the EWGSOP definition and diagnostic algorithm. J. Gerontol. A Biol. Sci. Med. Sci., 2014, 69(4), 438-446.

[20] Salmi, J. A.: Body composition assessment with segmental multifrequency bioimpedance method. J. Sports Sci. Med., 2003, 2(Suppl. 3), 1-29.

[21] Guralnik, J. M., Ferrucci, L., Pieper, C. F., et al.: Lower extremity function and subsequent disability: consistency across studies, predictive models, and value of gait speed alone compared with the short physical performance battery. J. Gerontol. A Biol. Sci. Med. Sci., 2000, 55(4), M221-M231.

[22] Laurentani, F., Russo, C. R., Bandinelli, S., et al.: Age-associated changes in skeletal muscles and their effect on mobility: an operational diagnosis of sarcopenia. J. Appl. Physiol., 2003, 95(5), 1851-1860.

[23] Steffen, T. M., Hacker, T. A., Mollinger, L.: Age- and gender-related test performance in community-dwelling elderly people: Six-Minute Walk Test, Berg Balance Scale, Timed Up and Go Test and Gait speeds. Phys. Ther., 2002, 82(2), 128-137.

[24] Del Tredici, A. M., Joy, A. B., Omelich, C. L., et al.: Evaluation study of the California Expanded Food and Nutrition Education Program: 24-hour food recall data. J. Am. Diet. Assoc., 1988, $88(2), 185-190$.

[25] Abmed, T., Haboubi, N.: Assessment and management of nutrition in older people and its importance to health. Clin. Interv. Aging, 2010, 5, 207-216.

[26] Bauer, J., Biolo, G., Cederholm, T., et al.: Evidence-based recommendations for optimal dietary protein intake in older people: a position paper from the PROT-AGE Study Group. J. Am. Med. Dir. Assoc., 2013, 14(8), 542-559. 
[27] OLEF population health survey. [OLEF lakossági egészségfelmérés.] http://www.oefi.hu/olef/OLEF2003/Jelentesek/ EgeszsegmagatartasOLEF2003.pdf [Hungarian]

[28] Special Eurobarometer 412. Sport and physical activity 2014. http://ec.europa.eu/public_opinion/index_en.htm

[29] Patel, K. V., Coppin, A. K., Manini, T. M., et al.: Midlife physical activity and mobility in older age: The InCHIANTI study. Am. J. Prev. Med., 2006, 31(3), 217-224.

[30] Caughey, C. E., Roughead, E. E.: Multimorbidity research challenges: where to go from here? J. Comorbidity, 2011, l(1), $8-10$.

[31] Ryu, M., Jo, J., Lee, Y., et al.: Association of physical activity with sarcopenia and sarcopenic obesity in community-dwelling older adults: the Fourth Korea National Health and Nutrition Examination Survey. Age Ageing, 2013, 42(6), 734-740.

[32] Tanimoto, Y., Watanabe, M., Sun, W., et al.: Sarcopenia and falls in community-dwelling elderly subjects in Japan: Defining sarcopenia according to criteria of the European Working Group on Sarcopenia in Older People. Arch. Gerontol. Geriatr., 2014, 59(2), 295-299.

[33] Anbalagan, V. P., Venkataraman, V., Pradeepa, R., et al.: The prevalence of presarcopenia in Asian Indian individuals with and without type 2 diabetes. Diabetes Technol. Ther., 2013, 15(9), 768-775

[34] Martinez, B. P., Batista, A. K., Gomes, I. B., et al.: Frequency of sarcopenia and associated factors among hospitalized elderly patients. BMC Musculoskelet. Disord., 2015, 16, 108.

[35] Walsh, M. C., Hunter, G. R., Livingstone, M. B.: Sarcopenia in premenopausal and postmenopausal women with osteopenia, os- teoporosis and normal bone mineral density. Osteoporosis Int., 2006, 17(1), 61-67.

[36] Makanae, Y., Fujita, S.: Role of exercise and nutrition in the prevention of sarcopenia. J. Nutr. Sci. Vitaminol. (Tokyo), 2015, 61(Suppl.), S125-S127.

[37] Leenders, M., van Loon, L. J.: Leucine as a pharmaconutrient to prevent and treat sarcopenia and type 2 diabetes. Nutr. Rev., 2011, 69(11), 675-689.

[38] Symons, T. B., Schutzler, S. E., Cocke, T. L., et al.: Aging does not impair the anabolic response to a protein-rich meal. Am. J. Clin. Nutr., 2007, 86(2), 451-456.

[39] Bollwein, J., Diekmann, R., Kaiser, M. J., et al.: Distribution but not amount of protein intake is associated with frailty: a crosssectional investigation in the region of Nürnberg. Nutr. J., 2013, 12, 109

[40] Paddon-Jones, D., Rasmussen, B. B.: Dietary protein recommendations and the prevention of sarcopenia. Curr. Opin. Clin. Nutr. Metab. Care, 2009, 12(1), 86-90.

[41] Rom, O., Kaisari, S., Aizenbud, D., et al.: Lifestyle and sarcopenia-etiology, prevention, and treatment. Rambam Maimonides Med. J., 2012, 3(4), e0024.

[42] Hock, M., Takács, K., Figler, M., et al.: Sarcopenia and exercise as determinants of well-being in elderly. A pilot study. J. Proactive Med., 2015, 3(1), 5-10

(Kovács Éva dr., Budapest, Vas utca 17., 1088 e-mail: kovacse@se-etk.hu)

\title{
A Magyar Belgyógyász Társaság 46. Nagygyűlése Időpont: 2016. november 17-19.
}

\section{Helyszín: Novotel Budapest Centrum (Régi Hotel Palace), Budapest, VIII., Rákóczi út 43-45.}

A kongresszus kiváló alkalom az ismeretek gyarapítására, összegzésére. A program a belgyógyászat és a határterületek széles skáláját öleli fel.

Az országból a legjobb szakemberek tartanak előadásokat.

A plenáris ülések mellett ez alkalommal is sor kerül szatellita szimpóziumokra, szabadelőadásokra és poszterbemutatókra, valamint a Családorvosok fórumára.

Újdonság, hogy az utolsó napon, szombaton a Semmelweis Egyetem Családorvosi Tanszékével közösen szervezett, külön is akkreditált program lesz.

\author{
A kongresszus honlapja: http://mbt46ngy.felabor.hu \\ Jelentkezni elektronikus úton, a fenti honlapon keresztül vagy postán lehet. \\ A jelentkezési lap letölthető.
}

A rezidensek számára a részvételi dij kedvezményes, szinte jelképes, orvostanhallgatóknak és PhD-hallgatóknak ingyenes.

Technikai szervezö: Felabor Hungary Kft.

Dr. Szalay Ferenc

Tel: 215-1224 vagy Tel/Fax: 210-1007

E-mail: felabor.hungary@gmail.com vagy szalay@bel1.sote.hu

Reméljük, hogy a kongresszuson előadóként és/vagy hallgatóként köszönthetjük.

Dr. Rácz Károly

az MBT elnöke 